\title{
THE EXPERIENCE OF INDONESIAN MIGRANT \\ WORKERS IN TAIWAN DURING COVID-19 \\ PANDEMIC: A ‘RIGHT-BASED’ ANALYSIS
}

\author{
Yuherina Gusman
}

National Chengchi University, Taiwan

\begin{abstract}
Covid-19, which has attacked the world since the end of 2019, has had a global impact both economically and socially to the world community. Taiwan is one of country categorized as quite successful in dealing with Covid-19. From December 2019 until March 2021 there were 177,578 reported cases in Taiwan with a total of 976 positive cases and resulted in 10 deaths. A very small number compared to other cases that occur in other parts of the world. However, behind all that successful story, migrant workers in Taiwan are still forgotten during the pandemics. Migrant workers, particularly Indonesian migrant workers, who make up the majority in Taiwan, receive the least sympathy and understanding from the community. Several human rights issues confronted Indonesia Migrant Workers during the Covid-19 pandemic, including discrimination, loss of spatial public space, strict mobility limitations, concern for the family in Indonesia, a higher burden of common mental health, and a lower quality of life than local society, difficulty accessing health services and masks, and difficulty returning home. The purpose of this paper is to demonstrate how Indonesian migrant workers' rights were violated in Taiwan during the two phases of the Covid-19 pandemic. The data was collected through interviews, observation, and then was analyzed using the "rights-based" approach. The first phase lasted from December 2019 to March 2020, when the pandemic was still in its early stages, and the second phase lasted from March 2020 to January 2021, after the Taiwan government succeeded in controlling the pandemic
\end{abstract}

\section{Keywords:}

Migrant Workers Right, Covid-19, Human Right Abuse, Indonesia Migrant Workers In Taiwan, Covid-19 In Taiwan

\footnotetext{
Abstrak

Covid-19 yang menyerang dunia sejak akhir tahun 2019, telah memberikan dampak global baik secara ekonomi maupun sosial kepada masyarakat dunia. Taiwan merupakan salah satu negara yang tergolong cukup berhasil dalam menangani Covid-19. Sejak Desember 2019 hingga Maret 2021 terdapat 177.578 kasus yang dilaporkan di Taiwan dengan total 976 kasus positif dan mengakibatkan 10 kematian. Jumlah yang sangat kecil dibandingkan kasus lain yang terjadi di belahan dunia lain. Namun, di balik semua kisah sukses itu, pekerja migran di Taiwan masih
} 
dilupakan selama pandemi. Pekerja migran, khususnya pekerja migran Indonesia yang merupakan mayoritas di Taiwan, paling sedikit mendapat simpati dan pengertian dari masyarakat. Beberapa persoalan HAM yang dihadapi Buruh Migran Indonesia selama pandemi Covid-19 antara lain diskriminasi, hilangnya ruang publik spasial, keterbatasan mobilitas yang ketat, kepedulian terhadap keluarga di Indonesia, beban kesehatan mental umum yang lebih tinggi, dan kualitas hidup yang lebih rendah dari masyarakat setempat, kesulitan mengakses layanan kesehatan dan masker, serta kesulitan untuk pulang. Tujuan dari makalah ini adalah untuk menunjukkan bagaimana hak-hak pekerja migran Indonesia dilanggar di Taiwan selama dua fase pandemi Covid-19. Pengumpulan data dilakukan melalui wawancara, observasi, kemudian dianalisis dengan menggunakan pendekatan "rights-based". Fase pertama berlangsung dari Desember 2019 hingga Maret 2020, ketika pandemi masih dalam tahap awal, dan fase kedua berlangsung dari Maret 2020 hingga Januari 2021, setelah pemerintah Taiwan berhasil mengendalikan pandemi.

\section{Kata Kunci:}

Hak Pekerja Migran, Covid-19, Pelanggaran Hak Asasi Manusia, Pekerja Migran Indonesia Di Taiwan, Covid-19 Di Taiwan

\section{A. PENDAHULUAN}

7 he World Health Organization (WHO) declared Covid-19 a public health emergency requiring international attention on January 30, 2020. This virus has claimed the lives of millions of people worldwide since it first emerged in China. Aside from the growing number of health and humanitarian victims, Covid19 has also wreaked havoc on the global economy. Taiwan is an outlier in that it has successfully controlled the spread of the Covid-19 virus. According to the Taiwan Disease Control Center, which was appointed by the government as the lead agency to combat the Covid-19 case, there were 189,458 reported Covid-19 cases in Taiwan until March 30, 2021, with only 1,030 testing positive. To date, there have been 10 positive patient mortality rates for Covid-19, which is a small number when compared to other countries around the world ${ }^{[1]}$.

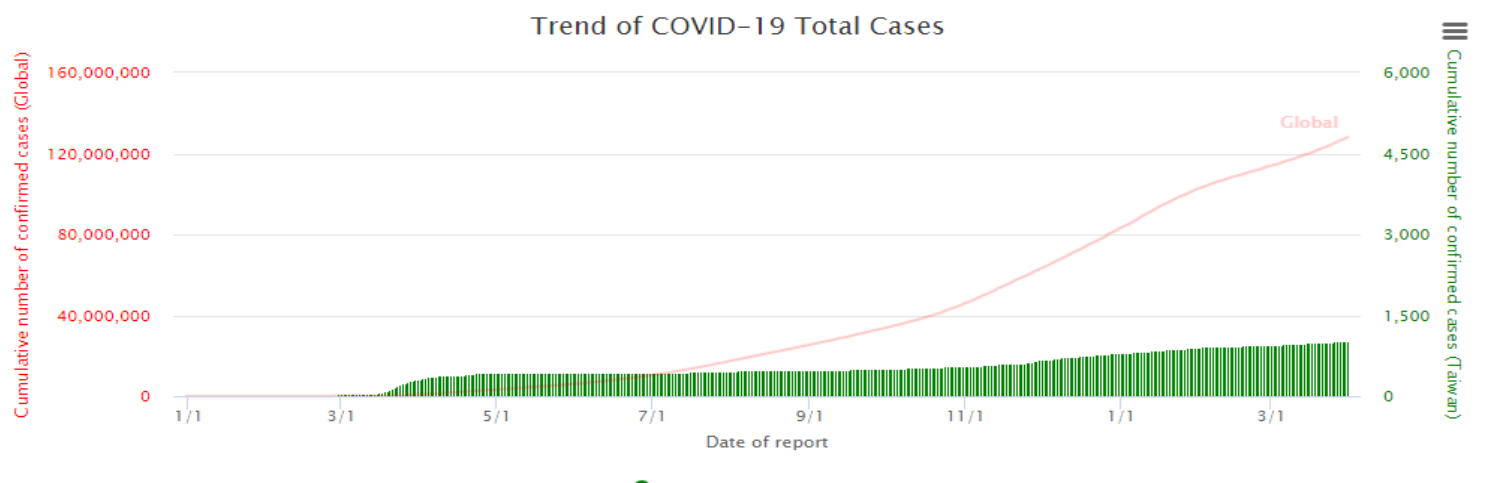

Source: https://covid19.mohw.gov.tw/

${ }^{[1]}$ https://www.cdc.gov.tw/En [Accessed 30 March 2021]

2 - लीवृำ 
Following the 2003 SARS outbreak, Taiwan implemented the Traffic Control Bundling (TCB) protocol, improved the culture of wearing masks and washing hands, and provided affordable health services to Covid-19 patients ${ }^{[2]}$. However, behind this success story, migrant workers remain the last group to receive attention during this pandemic. Taiwan has implemented two phases of pandemic response, the first from December 2019 to March 2020, and the second from April 2020 to March 2021.

\section{Indonesian Migrant Workers in Taiwan before the Covid-19 Pandemic}

Indonesian migrant workers constitute the majority of migrant workers in Taiwan, among the 712,107 total migrant workers in Taiwan 533,164 are from Indonesia, with $86 \%$ of whom are women ${ }^{[3]}$. The majority of these female migrant workers work as caregivers for the elderly, sick people, or disabled children. However, in addition to being assigned as care workers, these migrant workers are also assigned as domestic workers who are burdened with various types of domestic work Because of gender, class, and ethnicity, these migrant workers face crosssectoral discrimination, resulting in many of their rights not being met. It is common for them to work more than 18 hours a day, having no privacy, and frequently sleeping with the patients they care for, not having days off, experiencing psychological threats and physical harm, and frequently having to work outside the agreement in the work contract ${ }^{[4]}$. Despite their significant services and contributions to Taiwanese society, migrant workers are frequently viewed as an undesirable other. Their status as undesirable other causes many of their rights to be violated, including laws and policies that prevent them from naturalizing, deprive them of family life, and limit their mobility.

\section{The First Phase of the Covid-19 Pandemic in Taiwan (December 2019 - March 2020)}

Taiwan is geographically close to Wuhan, China; the distance between Taiwan and the coast of mainland China is 81 miles. Around 850.000 Taiwanese people live in China, and 404.000 of them work there. In 2019, the number of Chinese visitors to Taiwan is reached 2.71 million. Furthermore, COVID-19 took place just before the Lunar New Year, when millions of Chinese and Taiwanese were expected to travel for the holidays. In Taiwanese society, these conditions causes concern and panic. With these facts in hand, Taiwan was predicted to have the second-highest number of corona virus disease cases in $2019{ }^{[5]}$.

The first Covid-19 case in Taiwan was confirmed on 21 January, 2021, a 50-yearold woman who had just arrived at Taoyuan International Airport from her teaching

\footnotetext{
${ }^{[2]}$ Muh-Yong Yen, Jonathan Schwartz, Shey-Ying Chen, Chwan-Chuen King, Guang-Yang Yan, and PoRen Hsueh, "Interrupting COVID-19 transmission by implementing enhanced traffic control bundling: Implications for global prevention and control efforts", Journal of Microbiology, Immunology and Infection, Volume 53, Issue 3, June 2020, Pages 377-380

${ }^{[3]}$ http://statdb.mol.gov.tw/html/mon/c12030.htm [Accessed 30 March 2021]

${ }^{[4]}$ Isabelle Cheng, "We want productive workers, not fertile women: The expediency of employing Southeast Asian caregivers in Taiwan", Asia Pacific Viewpoint Vol. 61, No. 3, 2020 ISSN 1360-7456, pp453-465

${ }^{[5]}$ Wang CJ, Ng CY, Brook RH. Response to COVID-19 in Taiwan: Big Data Analytics, New Technology, and Proactive Testing. JAMA. 2020;323(14):1341-1342. doi:10.1001/jama.2020.3151, p.1 
job in Wuhan. She self-reported on her own initiative and was hospitalized despite the fact that she had no formal domestic entry. Taiwan's first domestic case was diagnosed on January 28, 2021, a man in his fifties was thought to have contracted the disease from his wife, who had traveled to Wuhan and had been confirmed before him ${ }^{[6]}$.

Taiwan quickly mobilized and implemented specific approaches to case identification, confinement, and resource allocation for public health protection in response to the swift cases in Taiwan and learned from miserable experience of the SARS pandemic in 2003. Some positive impacts of SARS pandemic in 2003 are Taiwanese people have developed good personal hygiene habits such as frequent hand-washing with soap and water, the use of face masks, and the taking of body temperatures.

Referring to the official CDC website, there are four preventive steps taken by the Taiwanese government, namely:

a.Operational Structure

On January 27, 2020, the stated the situation as Level 1 . This decision was made due to the deterioration of the global epidemic situation. Under the coordination of the Minister of Health and Welfare, Dr. Shih-Chung Chen, all ministries are involved in dealing with this situation. The explanation of each Level presented as follows ${ }^{[7]}$ :

\begin{tabular}{|c|l|c|}
\hline Levels & \multicolumn{1}{|c|}{ Suggestions } & \multicolumn{1}{|c|}{$\begin{array}{c}\text { Included } \\
\text { Countries/Region }\end{array}$} \\
\hline Level 1 : Watch & $\begin{array}{l}\text { Local prevention measures } \\
\text { should be followed. } \\
\text { Upon arrival, self-quarantine } \\
\text { for 14 days is required. }\end{array}$ & None \\
\hline Level 2: Alert & $\begin{array}{l}\text { Additional safeguards are } \\
\text { required. } \\
\text { Upon arrival, self-quarantine } \\
\text { for 14 days is required. }\end{array}$ & None \\
\hline Level 3 : Warning & $\begin{array}{l}\text { Avoid all unnecessary travel. } \\
\text { Upon arrival, self-quarantine } \\
\text { for 14 days is required. }\end{array}$ & Global \\
\hline
\end{tabular}

Source: Central Epidemic Command Center (CECC)

b.Legislation

In Taiwan, the Communicable Disease Control Act was enacted to prevent and control infectious diseases. In addition, on February 25, 2020, a Special Act for Prevention, Relief, and Revitalization Measures for Severe Pneumonia with Novel Pathogens was passed in response to the impending crisis.

c.Prevention Strategies

When cases of corona virus began to emerge in Wuhan, China, on December

${ }^{[6]}$ Chen, Wei-ting; Kao, Evelyn (21 February 2020). "WUHAN VIRUS/Taiwan confirms 1st Wuhan coronavirus case (update)". Central News Agency.

${ }^{[7]}$ https://covid19.mohw.gov.tw/ [Accessed 30 March 2021]

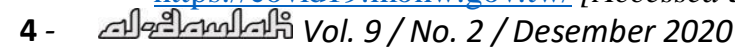


31, 2019, the Taiwanese government implemented relevant prevention strategies, including laboratory surveillance and diagnosis, border control, community transmission control, medical system response and preparedness, stockpiling and allocation. Taiwan conducted onboard quarantine inspections of direct flights from Wuhan, China, from December 31, 2019 to January 23, 2020, and promoted related prevention measures among other travelers.

d.Control of Community Transmission

People who have had contact with confirmed cases will be isolated at home for 14 days; due to the increasing number of people undergoing home quarantine, the Tourism Bureau has implemented a subsidy plan for hotels to provide rooms for people under home quarantine; and, during the early stages of the global Covid-19 outbreak, schools in Taiwan had delayed opening. Social distancing measures were announced on April 1, 2020.

Aside from the above strategies for preventing the corona virus outbreak in Taiwan, the government plays an important role in preparing and managing the availability of masks for its population. The National Face Mask Team was quickly formed to carry out the government proposal to construct 60 face mask production lines by January 31, 2020. Within two months, they had assembled 92 new face mask production lines capable of producing tens of millions of face masks per day.

Beside above strategies to prevent the outbreak corona virus in Taiwan, government play important role to prepare and manage the availability of mask for its population. National Face Mask Team was soon be formed to execute the government proposal to build 60 face mask production lines on January 31, 2020. Within 2 months, they assembled 92 new face mask production lines producing over tens millions of face masks daily. To guarantee that each citizen can obtain face masks equally, the Taiwan government launched the Name-Based Mask Distribution System on February 6, 2020, allowing citizens to purchase a particular number of face masks at 6,000 NHI-contracted drugstores across the country using their NHI card ${ }^{[8]}$. Second Phase of the Covid-19 Pandemic in Taiwan (April 2020 - March 2021)

Taiwan has successfully maintained 0 positive cases of covid-19 local transmission cases since April 12, 2020. SARS experiences, the Central Epidemic Command Center, information transparency, good resource allocation, timely border control, smart community transmission prevention, advanced medical technology, and good citizen etiquette are key success factors ${ }^{[9]}$. The CDC reported that Taiwan had no local cases of Covid-19 transmission for 200 days until October 2020, prompting the government to loosen covid-19 health protocol. Due to the large number of new cases brought by migrant workers, particularly from Indonesia, and the outbreak of a new type of virus from the UK, the partial international lockdown (entry restriction for foreigners) that had been in effect since 2 February 2020 was lifted and tightened in December 2020. As a result of the changing situation during

\footnotetext{
${ }^{[8]}$ Ministry of Health and Welfare. Taiwan Model for Combating Covid-19. December 2020

${ }^{[9]}$ Wang CJ, Ng CY, Brook RH. Response to COVID-19 in Taiwan: Big Data Analytics, New Technology, and Proactive Testing. JAMA. 2020;323(14):1341-1342. doi:10.1001/jama.2020.3151, p.2 
the covid-19 pandemic, several policies affecting migrant workers were implemented.

Observing the conditions of Indonesian migrant workers prior to the outbreak of Covid-19 and the subsequent phases of Covid-19 management by the Taiwan government, the question that arises is: Are Indonesian migrant workers treated the same during this pandemic? What about the realization of their human rights? Because many of their rights were not properly fulfilled prior to the outbreak of the pandemic. This paper attempts to provide answers to those questions.

\section{B. RESEARCH METHOD}

This paper describes the conditions of Indonesian migrant workers in Taiwan during the Covid-19 pandemic using a "rights-based" approach. The right-based approach analysis focuses on understanding the norms, standards, and principles of human rights and international humanitarian law that are applied to humanitarian intervention and development policies, services, and processes related to violence against women. The "rights-based" approach is, in principle, a conceptual framework that is normatively based on international human rights standards and operationally directed to promote and protect human rights. It seeks to examine obligations, inequality, and vulnerability, as well as to address discriminatory practices and unequal power distribution that impede and undermine human rights. Universality, non-discrimination and equality, indivisibility, participation, and accountability are the fundamental principles held in this matter ${ }^{[10]}$. The examples are: the International Convention on the Protection of the Rights of all Migrant Workers and Members of their Families (1990), ILO conventions (No. 97 migration for employment, 143 on migrant workers, 189 on decent work for domestic workers) and recommendations (R202 on social protection floors, or on the informal economy R204) ${ }^{[11]}$.

This paper will focus on the Taiwanese government's policies toward migrant workers, particularly Indonesian migrant workers, as well as society's response to migrant workers during the outbreak. Data is gathered to support the analysis by following the development of Covid-19 in Taiwan and its relationship with Indonesian migrant workers through news, direct interviews with migrant workers, and social media analysis on Facebook, either through personal Facebook or Facebook groups of Indonesian migrant workers in Taiwan.

\section{RESULT AND DISCUSSION}

The Covid-19 pandemic has a global impact on the workforce, and migrant workers are no exception. Migrant workers are frequently overlooked when it comes to accessing Covid-19 measures implemented by the countries where they work, such as financial assistance packages, wage subsidies, income support, and social

\footnotetext{
${ }^{[10]}$ http://uucsj.org/wp-content/uploads/2019/10/Introduction-to-the-Rights-Based-Approach.pdf [Accessed 30 March 2021]

${ }^{[11]}$ Hujo, K. (2019). A global social contract: New steps towards a rights-based approach to migration governance? Global Social Policy, 19(1-2), 25-28. https://doi.org/10.1177/1468018119849232

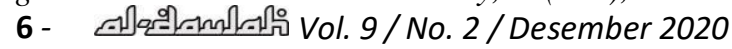


protection ${ }^{[12]}$. This is because, prior to the pandemic, migrant workers were often considered invisible, had inadequate living conditions, limited access to health care and basic services, poor working conditions, and were frequently exploited. Indonesian migrant workers in Taiwan face the same challenges: they must work 20 hours per day, do extra work for no extra pay, have no privacy, and are frequently subjected to physical and verbal abuse.

\section{Indonesian Migrant Workers during Phase One of the Covid-19 Pandemic in Taiwan} (December 2019 - March 2020)

Taiwan was one of the countries that feared a similar virus outbreak that occurred in Taiwan at the start of the coronavirus outbreak in Wuhan, China, at the end of 2019. Given that the distance between Wuhan and Taiwan is only 1,010 kilometers, and that many Taiwanese live in Wuhan on a temporary or permanent basis. Furthermore, the emergence of this virus coincides with the Chinese New Year celebrations in 2020, when hundreds of Taiwanese living in Wuhan will have returned to Taiwan. Following the 2003 SARS outbreak, which claimed many lives in Taiwan, the government immediately implemented four major policies: the establishment of the CECC, restrictions on domestic mobility, a partial lockdown by canceling all international flights, and the enforcement of health protocols. The use of masks, social distance, and temperature checking are among the health protocols implemented. During this stage, migrant workers face issues such as masks and social distance.

Taiwan experienced a mask crisis at the start of the Covid-19 pandemic. Despite the fact that the government has been in charge of mask procurement and distribution since February 6, 2020, many migrant workers have had difficulty obtaining them. Most migrant workers work in homes where their mobility is restricted by their employers and they are unable to leave freely (i.e. their place of work). Because migrant workers do not have regular days off, it is difficult for them to purchase masks. Even if they are permitted to purchase face masks at their local pharmacy, they may be unable to join the long lines because most employers are less tolerant of their absence from work. Furthermore, most migrant workers caring for patients required more masks than were provided (two in one week). They must accompany their patients to a hospital or clinic for rehabilitation or dialysis; in some cases, rehabilitation therapy necessitates daily visits to a medical facility. Face masks are recommended in hospitals or health institutions due to the increased risk of infection. As a result, two face masks per week may not be enough to meet the needs of caregivers and those they care for ${ }^{[13]}$. Some employers are kind enough to purchase masks for their employees, but due to a limited supply, masks are frequently prioritized for patients, requiring migrant workers to wear masks multiple times. Aside from not adhering to the standard of wearing masks, this increases their risk of

${ }^{[12]}$ L. Foley and N. Piper, COVID-19 and women migrant workers: Impacts and implications, IOM, Geneva, 2020

${ }^{[13]}$ Ying-da Wong, Migrant Workers Struggle to Secure Masks in Taiwan amid COVID-19 Fear, https://english.cw.com.tw/article/article.action?id=2671, [Accessed 30 March 2021] 
being infected with the virus. Migrant workers' health is not a priority for their employers. In addition to increasing the risk of exposure, this causes migrant workers to experience increased stress and anxiety. Due to a lack of support, many migrant workers are unsure how to address this issue. As a result, confiding in social media platforms such as Facebook is one of their stress-relieving strategies.

Social distance is one of the health protocols that must be implemented during the Covid-19 outbreak, either by the Taiwan government or in accordance with the IOM guidance Protection for Migrant Workers during the Covid-19 Pandemic. However, social distance is difficult for migrant workers to apply in Taiwan, where factory workers typically live in a single dormitory. One of the interviewees admitted to living in a $3 \times 4$-meter room with five other workers. It is difficult to maintain social distance, and they must share the bathroom, increasing the risk of virus transmission. They were not provided with masks during the mask crisis and had to purchase them on their own. The issue is that sometimes masks are not sold on Saturdays or Sundays, despite the fact that they are only holidays on those days. Another acknowledgement comes from a migrant worker who works as a caregiver and admits that she sometimes has to sleep next to the patient while caring for them in the hospital. Maintaining social distance with the patient and other migrant workers in the hospital is extremely difficult.

Another source of social distance is the government's policy of prohibiting migrant workers from congregating in the Taipei main station hall. Before social distancing, the main hall of Taipei Main Station was a social gathering place for migrant workers. Discrimination against migrant workers is becoming more severe, with some even saying things that are offensive to migrant workers, such as the following sentence conveyed by a cleaner at TMS to migrant workers from Indonesia, "'Hey, you're a migrant, you have to sit outside, not here because you brought the virus to us"[14]. The treatment to the workers by Taiwanese people during the pandemic period emphasized their presence as undesirable others. In this case, a double standard occurred because, due to the employer's inability to provide adequate living conditions for the workers, they rarely pay attention to social distance. On the other hand, for reasons of social distance, Taiwanese do not permit workers to congregate in the hall of Taipei Main Station. Moreover, many employers restrict the consent for migrant workers to have days off due to the pandemic situation.

\section{Indonesian Migrant Workers Phase Two of the Covid-19 Pandemic in Taiwan (April 2020 - March 2021)}

Taiwan's situation improved during the second phase of the Covid-19 pandemic. Taiwan's ability to produce 10 million masks per day solved the mask crisis. Mass production sufficient for local needs and the ability to donate some to many countries around the world. As long as the citizen have national health insurance (NHI), the government provides the same and equitable health services to

${ }^{[14]}$ Daphne K. Lee. , 'You Brought the Virus to Us': Taipei Main Station Sitting Ban an Attack on Migrants, https://international.thenewslens.com/article/135330 [Accessed 30 March 2021]

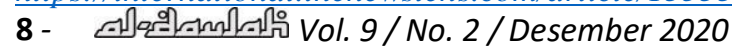


everyone, including migrant workers ${ }^{[15]}$. Undocumented migrant workers who do not have NHI, live in groups, and move around have been identified as potential carriers and spreaders of the virus. As a result, the government issued an amnesty policy allowing undocumented migrant workers to surrender and return to their home countries. This amnesty policy eliminates fines for illegal workers and excludes them from the blacklist, allowing them to return to work in Taiwan. This program was available from April 1st to June 30th, 2020. This program was successful in repatriating 2,700 of 53,000 undocumented migrant workers in Taiwan ${ }^{[16]}$. However, the policy does not address the root cause of the problem; the number of undocumented migrant workers remains high, and they are unable to access medical care if they are infected with the covid-19 virus.

In this second phase, Indonesian migrant workers have been temporarily suspended since December 4, 2021. The reason is due to 22 imported cases of covid19 brought by migrant workers in November 2021. Twenty of the 22 cases were from Indonesia. This situation causes Taiwan to have a labor shortage, which increases the number of cases of migrant worker exploitation. As one of the respondents who worked in a nursing home stated. The workload was increasing because many of her colleagues had returned to Indonesia and new workers were unable to enter. Normally, one caregiver can only treat nine patients, but during a pandemic, this can be increased to nearly five times. Time and workload increase, but workers do not receive a raise or bonus. During the Covid-19 period, migrant workers experienced an increase in mental health problems due to a heavy workload and an uncertain situation. Economic difficulties in both the origin and destination countries have added to the workers' mental burden. Not to mention the concern for families left behind in Indonesia as the country's pandemic situation worsens. The increased number of imported cases of covid-19 from migrant workers has also increased discrimination against them. Many Taiwanese keep their distance from migrant workers out of fear that they will spread the viruses.

\section{CONCLUSION}

The Covid-19 pandemic wreaked havoc on the world. While governments work to reduce the virus's spread, issues concerning human rights, including migrant workers, continue to arise. Prior to the Covid-19 pandemic, migrant workers had difficulty accessing justice, and Covid-19 exacerbated this justice gap. Although the Taiwanese government was successful in preventing and dealing with the Covid-19 pandemic, efforts to avoid treating migrant workers as undesirable others are still insufficient. The policies enacted have not been fully pro-migrant workers; on the contrary, the local and native Taiwanese have been prioritized without regard for the

${ }^{[15]}$ Vincent Yi-Fong Su et.al, Masks and medical care: Two keys to Taiwan's success in preventing COVID19 spread, Travel Med Infect Dis. 2020 November-December; 38: 101780. Published online 2020 Jun 4. doi: 10.1016/j.tmaid.2020.101780

${ }^{[16]}$ https://www.straitstimes.com/asialeast-asialtaiwan-sees-results-with-amnesty-to-get-illegal-workers-tosurface [Accessed 30 March 2021] 
impact on migrant workers. If the policy is for the good or safety of Taiwanese, migrant workers will be considered. A "rights-based" approach to analyzing Taiwanese government policies on migrant workers reveals that discrimination, inequality, and non-participation are becoming more pronounced. The pandemic of covid-19 exacerbates the humiliation of migrant workers' basic human rights. Workers become more invisible, are not prioritized when the government makes policies related to covid-19, are subjected to double pressure on working conditions, and are more vulnerable to mental health illness.

\section{References}

Chen, Wei-ting; Kao, Evelyn (2020). WUHAN VIRUS/Taiwan confirms 1st Wuhan coronavirus case (update). Central News Agency.

Daphne K. Lee. (2020). 'You Brought the Virus to Us': Taipei Main Station Sitting Ban an Attack on Migrants, https://international.thenewslens.com/article/135330 [Accessed 30 March 2021]

Hujo, K. (2019). A global social contract: New steps towards a rights-based approach to migration governance? Global Social Policy, 19(1-2), 25-28. https://doi.org/10.1177/1468018119849232

Isabelle Cheng. (2020). We want productive workers, not fertile women: The expediency of employing Southeast Asian caregivers in Taiwan. Asia Pacific Viewpoint Vol. 61, No. 3, 2020 ISSN 1360-7456, pp453-465

L. Foley and N. Piper. (2020). COVID-19 and women migrant workers: Impacts and implications. IOM, Geneva

Ministry of Health and Welfare Taiwan. (2020). Taiwan Model for Combating Covid19.

Muh-Yong Yen, et.al (2020). Interrupting COVID-19 transmission by implementing enhanced traffic control bundling: Implications for global prevention and control efforts. Journal of Microbiology, Immunology and Infection, Volume 53, Issue 3, Pages 377-380

Vincent Yi-Fong Su et.al,(2020). Masks and medical care: Two keys to Taiwan's success in preventing COVID-19 spread. Travel Med Infect Dis. 2020 November-December; 38: 101780. doi: 10.1016/j.tmaid.2020.101780

Wang CJ, Ng CY, Brook RH. (2020). Response to COVID-19 in Taiwan: Big Data Analytics, New Technology, and Proactive Testing. JAMA.323(14):1341-1342. doi:10.1001/jama.2020.3151

Wei, Katherin. (2020). Coronavirus: Taiwan sees results with amnesty to get illegal workers to surface. https://www.straitstimes.com/asia/east-asia/taiwan-seesresults-with-amnesty-to-get-illegal-workers-to-surface

Ying-da Wong. (2020). Migrant Workers Struggle to Secure Masks in Taiwan amid COVID-19 Fear, https://english.cw.com.tw/article/article.action?id=2671, [Accessed 30 March 2021]

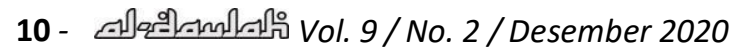

